\title{
₹USGS
}

science for a changing world

\section{Debris-Flow Hazards Caused by Hydrologic Events at Mount Rainier, Washington}



\section{U.S. Geological Survey Open-File Report 03-368}

U.S. Department of the Interior

U.S. Geological Survey 
Cover photo: Debris flow descending Comet Falls on 15 August 2001 (Photo by J.W. Vallance). 


\section{Debris-Flow Hazards Caused by Hydrologic Events at Mount Rainier, Washington}

By James W. Vallance, Michelle L. Cunico, and Steve P. Schilling

\section{U.S. Geological Survey \\ Open-File Report 03-368}

This report is preliminary and has not been reviewed for conformity with U.S. Geological Survey editorial standards. Any use of trade, product, or firm names is for descriptive purposes only and does not imply endorsement by the U.S. Government.

Vancouver, Washington

2003 


\section{U.S. Department of the Interior \\ Gale A. Norton, Secretary}

\section{U.S. Geological Survey \\ Charles G. Groat, Director}

Although this report is in the public domain, permission must be secured from the individual copyrigh owners to reproduce any copyrighted material contained within this report.

For more information about Cascade Volcanoes contact:

U.S. Geological Survey

Cascades Volcano Observatory

1300 SE Cardinal Court, Building 10, Suite 100

Vancouver, WA 98683-9589

(360) 993-8900

FAX (360) 993-8980

http://vulcan.wr.usgs.gov/
For more information about the USGS and its products:

Telephone: 1-888-ASK-USGS

World Wide Web: http://www.usgs.gov/ 


\section{Contents}

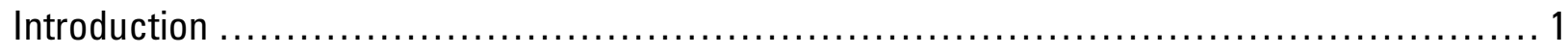

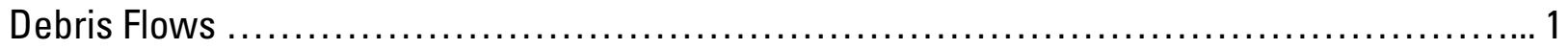

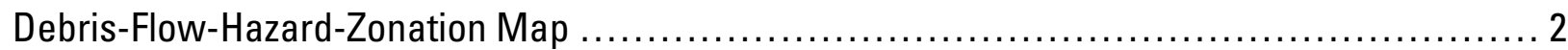

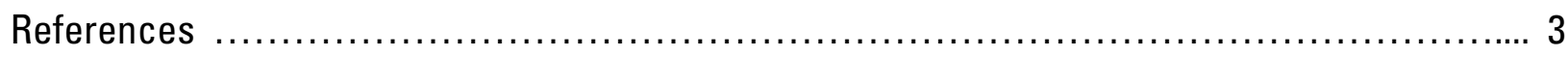

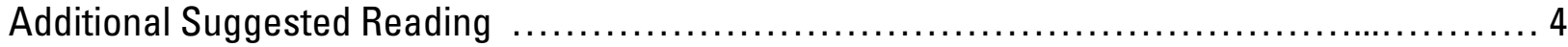

\section{Plates}

1. Map Showing Areas of potential Inundation from Debris Flows for Selected Streams at Mount Rainier, Washington.

2. Maps Showing Areas of potential Inundation from Debris Flows for Selected Streams at Mount Rainier, Washington. Detailed maps of selected areas from plate 1. 


\title{
Debris-Flow Hazards Caused by Hydrologic Events at Mount Rainier, Washington
}

\author{
By James W. Vallance, Michelle L. Cunico, and Steve P. Schilling
}

\section{Introduction}

At 4393 m, ice-clad Mount Rainier has great potential for debris flows owing to its precipitous slopes and incised steep valleys, the large volume of water stored in its glaciers, and a mantle of loose debris on its slopes. In the past 10,000 years, more than sixty Holocene lahars have occurred at Mount Rainier (Scott et al., 1985), and, in addition more than thirty debris flows not related to volcanism have occurred in historical time (Walder and Driedger, 1984). Lahars at Mount Rainier can be classed in 3 groups according to their genesis: (1) flank collapse of hydrothermally altered, water-saturated rock; (2) eruption-related release of water and loose debris; and (3) hydrologic release of water and debris (Scott et al., 1985). Lahars in the first two categories are commonly voluminous and are generally related to unrest and explosions that occur during eruptive episodes. Lahars in the third category, distinguished here as debris flows, are less voluminous than the others but occur frequently at Mount Rainier, often with little or no warning.

Historically at Mount Rainier, glacial outburst floods, torrential rains, and stream capture have caused small- to moderate-size debris flows (Walder and Driedger, 1984). Such debris flows are most likely to occur in drainages that have large glaciers in them. Less commonly, a drainage diversion has triggered a debris flow in an unglaciated drainage basin. For example, the diversion of Kautz Glacier meltwater into Van Trump basin triggered debris flows on the south side of Rainier in August 2001.

On the basis of historical accounts, debris flows having hydrologic origins are likely to be unheralded, and have occurred as seldom as once in 8 years and as often as four times per year at Mount Rainier (Walder and Driedger, 1984). Such debris flows are most likely to occur during periods of hot dry weather or during periods of intense rainfall, and therefore must occur during the summer and fall. They are likely to begin at or above the elevations of glacier termini and extend down valley.

This report discusses potential hazards from debris flows induced by hydrologic events such as glacial outburst floods and torrential rain at Mount Rainier and the surrounding area bounded by Mount Rainier National Park. The report also shows, in the accompanying hazard-zonation maps, which areas are likely to be at risk from future such debris flows at Mount Rainier. Lahar hazards related to avalanches of altered rock and to the interactions of hot rock and ice during eruptions are discussed in Scott and Vallance (1995) and Hoblitt et al. (1998) and are not addressed in this report.

\section{Debris flows}

Debris flows are water-saturated mixtures of mud, rock, and water having a large sediment concentration that move down slope under the influence of gravity. They occur when water mobilizes large volumes of loose mud, rock, and other debris. Commonly, sudden water floods that travel along steep channels lined with abundant loose volcanic or glacial debris incorporate enough debris to become debris flows. Debris flows, like floods, inundate floodplains and structures in low-lying areas. They can travel many tens of kilometers down valleys at speeds of tens of kilometers per hour. Debris flows destroy or damage everything in their paths through burial or impact. They follow river valleys and leave deposits of muddy sand and gravel that can be several meters thick. Large rock fragments carried by debris flows make them especially destructive; abundant liquid contained in them allows them to flow over gentle gradients 10 $\mathrm{km}$ or more from their sources. People downstream commonly neither expect the danger nor anticipate the destructive power of debris flows. 
Like floods, debris flows range greatly in size. The smallest debris flows occur most frequently (perhaps every few years), whereas the largest recur on the order of a century. The amount of water and loose volcanic debris entrained determines debrisflow size. Severe meteorological events, like that at Kautz Creek in 1947, can deposit millions of cubic meters of sediment into channels and damage or destroy important Park infrastructure.

\section{Debris-flow Hazard- Zonation Map}

The accompanying debris-flow hazardzonation maps (plates 1 and 2) shows areas that could be inundated by future debris flows originating at Mount Rainier and extending into valleys downstream. Individual debris flows typically affect only part of a hazard zone. The location and size of an affected area will depend on local conditions, such as the volume of material involved and mode of initiation. Sudden-onset debris flows are likely to inundate greater areas than debris flows that develop over significant intervals of time or debris flows that have multiple pulses separated by significant time intervals.

Hazard zones begin at glacier termini or margins because these areas are historically where debris flows of hydrologic origins begin. Debrisflow hazard zones are subdivided on the basis of their relative degree of hazard. Hazard-zone boundaries derive from three main factors. First, there are the magnitudes of debris flows known to have occurred at Mount Rainier, as inferred from historical accounts and prehistoric deposits. Second, an empirical model estimates debris-flow-inundation limits on the basis of debris flows of known volume that have occurred at other volcanoes. Third, we apply our experience and judgment derived from past experience with events of a similar nature elsewhere.

Although sharp boundaries delineate each hazard zone, the limit of the hazard does not end abruptly at the boundaries. Rather, the hazard decreases gradually as distance from the glacier termini at Mount Rainier increases and decreases rapidly with increasing elevation above valley floors. Areas immediately beyond distal hazard zones are not free of risk because the hazard limits can only approximately be located, especially in areas of low relief. Many uncertainties about the source, size, and mobility of future debris flows preclude precise location of the hazard-zone boundaries.

Users of our hazard map should be aware that we have not simulated all hazardous debris-flow scenarios. In particular, we have simulated neither volcanigenic lahar inundations nor inundations generated by debris avalanches of hydrothermally altered rock. The edifice of Mount Rainier volcano is steep, incised, and partly affected by hydrothermal weakening of the rock and debris flows could potentially develop in any of these areas. For this report, we selected prominent channels headed by glaciers in order to define the most significant zones of inundation from debris flows of various volumes. Other channels for which we have not modeled debris-flow inundation are not necessarily devoid of hazard. Debris flows from other unmapped channels could also threaten life and property.

An automated empirical technique calibrated with data from other volcanoes (Iverson et al., 1998; Schilling, 1998) estimates potential areas of inundation from debris flows of various volumes. For each channel analyzed, we define eight nested hazard zones that depict anticipated inundation by hypothetical "design" debris flows having different volumes. The largest design debris flow reflects our estimate of the largest probable debris flow generated by hydrologic events at Mount Rainier (plate 1). The two smallest design debris flows are representative of the most common debris-flow volumes.

The most voluminous recorded debris flows (38 million cubic meters) at Mount Rainier occurred because of torrential rains during the night of October 2 and early morning of October 3, 1947, in Kautz Creek (Crandell, 1971). A period of heavy rain began October 1, reached its greatest intensity the evening of October 2, and dissipated on October 3. Crandell cites first-hand accounts and field observations of deposits that show the Kautz Creek event comprised initial floods followed by at least 4 debris flows. Although the total accumulation of debris is about 38 million cubic meters, probably no individual flow of the 1947 sequence exceeded 16 million cubic meters, and we use 16 million cubic meters as a maximum probable volume in our model. The cumulative areal extent of the 1947 deposits is approximately that of our model run of 4 million cubic meters. The discrepancy results because the 1947 event occurred over a period of 12 hours and involved at least 4 separate pulses, whereas our 
model assumes sudden onset. We propose that a debris flow like the 1947 event in size and origin would inundate a similar area $\left(4 \times 10^{6} \mathrm{~m}^{2}\right)$ and be representative of the maximum historical event. An event on the scale of the 1947 Kautz Creek debris flow has an approximate recurrence of once every 100 to 200 years.

More than 30 debris flows with volumes of 1 to 3 million cubic meters have occurred historically at Mount Rainier, and 23 of these occurred in Tahoma Creek between 1967 and 1993 (Richardson, 1968; Walder and Driedger, 1994). These debris flows resulted from glacier outburst floods, intense precipitation, or both. Some occurred during periods of hot dry weather, and others occurred during rainstorms. They all occurred in summer or early fall. In the past 100 years, such debris flows have occurred in Tahoma Creek, Kautz Creek, Nisqually River, and West Fork White River. The most recent of these in August 14-15, 2001, were unusual in that a diversion of Kautz Glacier meltwater into the Van Trump drainage basin during hot dry weather triggered several debris flows and mobilized 2.5 million cubic meters of debris (Vallance et al., 2002). Debris flows with volumes on the order of $10^{6} \mathrm{~m}^{3}$ are common. As many as 4 have occurred in one year and since 1960 at least 27 have occurred. Since 1924, there have been at least 35 debris flows Parkwide, thus, the average probability of a debris flow $10^{6} \mathrm{~m}^{3}$ occurring during a given year is about 1 in 2 (Driedger and Fountain, 1989, and Walder and Driedger, 1995).

We constructed debris-flow-hazard zones by choosing design-lahar volumes of 125,000, 250,000; 500,000; 1,000,000; 2,000,000; 4,000,000; $8,000,000$; and 16,000,000 cubic meters. We then modeled a debris flow for each volume using the repeatable empirical model and digital cartographic technique described in Iverson et al. (1998). The model requires the choice of a reasonable range of volumes for each volcano. It then uses these volumes to compute average cross-sectional areas and areas of inundation for each modeled debris flow. The GIS based computer program, LAHARZ (Iverson et al., 1998; Schilling, 1998) then calculates the extent of inundation downstream in all drainages that head on the volcano.

Large debris flows are less likely to occur than small debris flows. Thus, the nested debris-flow hazard-inundation zones show that the likelihood of debris-flow inundation decreases as distance from the source and as elevation above the valley floors increases. Debris flows of all designated sizes could form on Mount Rainier if the right meteorological and hydrologic conditions coincide. Although the largest design debris flow (plates 1 and 2) is based on the size of the largest debris flow that occurred in Kautz Creek in 1947, the cumulative area inundated by an event of that magnitude is shown by our 4 million cubic meters hazard zone. An intense storm would not invariably trigger debris flows as large as those of Kautz Creek. Debris-flow inundation zones represented by 8 million cubic meters and 16 million cubic meters represent outlier events larger than that of 1947 in Kautz Creek.

In general, debris-flow-hazard zones extend 5 to 25 kilometers from the glacier termini (plate 1), but the most likely design-case scenarios would inundate only areas within the boundaries of Mount Rainier National Park. Local topography plays a large role in controlling debris-flow travel distance. Debris flows of a given volume will move considerably greater distances in steep confined drainages than in broad drainages with gentle gradients. Despite their relatively short runout distances, even moderate volume debris flows moving southward along the Nisqually River toward Cougar Rock Campground or Longmire and along Tahoma Creek toward the Westside Access Road could pose a threat because of nearby Park infrastructure in those directions. Model runs suggest that White River Campground is at risk only from moderate to large debris flows.

\section{References}

Driedger, C.L. and Fountain, A.G., 1989, Glacier outburst floods at Mount Rainier, Washington State, U.S.A.: Annals of Glaciology, v. 13, p. 51-55.

Hoblitt, R.P., Walder, J.S., Driedger, C.L., Scott, K.M., Pringle, P.T., and Vallance, J.W., 1998, Volcano hazards from Mount Rainier, Washington, revised 1998: U.S. Geological Survey Open-File Report 98-428, 11p.

Iverson, R.M., Schilling, S.P., and Vallance, J.W., 1998, Objective delineation of lahar-hazard zones downstream from volcanoes: Geological Society of America Bulletin, v. 110 , p. $972-984$. 
Richardson, D., 1968, Glacier outburst floods in the Pacific Northwest: U.S. Geological Survey Professional Paper 600-D, p. 79-86.

Schilling, S.P., 1998, LAHARZ: GIS programs for automated mapping of lahar-inundations hazard zones: U.S. Geological Survey Open-File Report 98-638, 80p.

Scott, K.M. and Vallance, J.W., 1995, Debris flow, debris avalanche, and flood hazards at and downstream from Mount Rainier, Washington: U.S. Geological Survey Hydrologic Investigations Atlas HA-729.

Scott, K.M. and Vallance, J.W., 1995, Sedimentology, behavior, and hazards of debris flows at Mount Rainier, Washington: U.S. Geological Survey Professional Paper 1547, 56 p., 1 plate.

Vallance, J. W., Driedger, C.L. and Scott, W.E., 2002, Washington Geology.

Walder, J.S. and Driedger, C.L., 1994, Geomorphic change caused by outburst floods and debris flows at Mount Rainier, Washington with emphasis on Tahoma Creek valley, U.S. Geological Survey Water-Resources Investigation Paper 93-4093, 93 p.
Walder, J.S. and Driedger, C.L., 1995, Frequent outburst floods from South Tahoma Glacier, Mount Rainier, U.S.A.: relation to debris flows, meteorological origin and implications for subglacial hydrology: Journal of Glaciology, v. 41 p. 1-10.

\section{Additional Suggested Reading}

\author{
Vallance, J.W. 2000, Lahars: in Sigurdsson, H., \\ Houghton, B., McNutt, S., Rymer, H., and \\ Stix, J., Encyclopedia of Volcanoes, \\ Academic Press, San Diego, p. 601-616.
}

